\title{
Depth of post-depositional remanence acquisition in deep-sea sediments: a case study of the Brunhes-Matuyama reversal and oxygen isotopic Stage 19.1
}

\author{
Peter B. deMenocal, William F. Ruddiman and Dennis V. Kent \\ Lamont-Doherty Geological Observatory and Department of Geological Sciences of Columbia University, Palisades, NY 10964 (U.S.A.)
}

Received November 14, 1989; revised version accepted April 11, 1990

ABSTRACT

\begin{abstract}
Although post-depositional remanent magnetization (PDRM) in deep-sea sediments appears to be acquired during the earliest stages of sediment compaction, the natural variability of the PDRM lock-in depth in deep-sea sediments is poorly understood and as yet unquantified. Here we consider variations in the relative stratigraphic positions of oxygen isotopic interglacial Stage 19.1 and the Brunhes-Matuyama (B/M) Chronozone reversal for eight deep-sea sediment cores. Results from a similar study of the displacement between a widespread microtektite layer and the $\mathrm{B} / \mathrm{M}$ boundary are also included [1]. The PDRM lock-in depth and the temporal relationships between the $\mathrm{B} / \mathrm{M}$ and Stage 19.1 datums can be determined from the offsets between the paleomagnetic and the isotopic (and microtektite) stratigraphies.

For cores with sedimentation rates greater than $1 \mathrm{~cm} \mathrm{kyr}^{-1}$, the depth offset between the paleomagnetic and isotopic datums is a linear function of sedimentation rate. A simple model $\left(r^{2}=0.77\right)$ demonstrates that (1) PDRM acquisition occurs $\sim 16 \mathrm{~cm}$ below the sediment surface, and (2) the B/M reversal occurs $6 \mathrm{kyr}( \pm 2 \mathrm{kyr})$ after the Stage $19.1 \mathrm{datum}$, and the Stage 19.1 datum occurs $9 \mathrm{kyr}( \pm 3 \mathrm{kyr}$ ) after the deposition of the Australasian microtektite strewnfield. This example argues against simple geophysical models linking geomagnetic field reversals to climate change or impact events.

The $\mathbf{B} / \mathbf{M}$ boundary is anomalously deep $(30-50 \mathrm{~cm})$ in very low accumulation rate sediments $\left(<1 \mathrm{~cm} \mathrm{kyr}^{-1}\right)$ and this may reflect the unusual physical properties of these sediments. A review of the geotechnical literature suggests that very low accumulation rate sediments have sufficient time to develop enhanced interparticle rigidity (structural strength) which inhibits early compaction and, hence, PDRM acquisition.
\end{abstract}

\section{Introduction}

Theoretical investigations have suggested that fine ferrimagnetic grains settling through the water column to the sediment surface align themselves almost instantaneously to the ambient magnetic field direction [2]. However, the resulting depositional remanent magnetization (DRM) is an ephemeral concept, since the fine grains are typically free to rotate in the high-porosity surface sediment which is often also thoroughly reworked by burrowing organisms. Irving [3] offered the term post-depositional remanent magnetization (PDRM) to describe the magnetization which is preserved after sufficient compaction and Kent [4] showed that PDRM is the magnetization which is typically measured in deep-sea sediments.
The processes which contribute to PDRM acquisition and its "lock-in" depth are not well understood despite numerous experimental and theoretical studies. Laboratory redeposition experiments have identified sediment consolidation as the most significant process affecting the acquisition of PDRM; some of these experiments have shown that there is often a considerable lag between the field change and the actual depth at which it is recorded [5,6]. Several theoretical studies have presented a physical basis for this observation [6-8]. In high-porosity surface sediments, fine magnetic grains are free to rotate in. the pore spaces since the torque exerted by the earth's field exceeds the physical restraint provided by the effective viscosity of the sediment. As the sediment is buried below the bioturbated zone, 
pore spaces are reduced and the ambient magnetization direction becomes locked in as the consolidation process overcomes the field torque. Thus, the depth of PDRM lock-in may be related to factors influencing early consolidation, which include grain size and shape, sediment composition and sedimentation rate [4]. Estimates for the PDRM lock-in zone in marine sediments range from 0.1 to $1.0 \mathrm{~m}$ below the sediment surface $[1,6,9,10,11]$.

\section{The strategy}

The aim of this study is to investigate the relationship between the paleomagnetic and isotopic stratigraphies for several deep-sea sediment cores with different sedimentation rates. Although consolidation seems to be the dominant factor influencing PDRM acquisition, little is known about the natural variability of the lock-in process, especially with sedimentation rate. Magnetic reversals and marker beds are stratigraphically preserved by different processes: PDRM lock-in is controlled by early compaction below the wellmixed bioturbation zone, whereas particulate tracers such as isotopic or microtektite markers are displaced mainly by bioturbation. Furthermore, both compaction and bioturbation can be expected to vary with sedimentation rate. Because it is possible to "unmix" the isotopic stratigraphies to their original pre-bioturbated positions [12-15], the effects of bioturbation can be removed and the natural variability of the PDRM lock-in depth can be isolated and examined.

\subsection{Post-depositional acquisition of the oxygen iso- tope record}

Variations in the oxygen isotopic content of planktonic or benthic foraminifera reflect variations in the temperature of test calcification (a disequilibrium effect) and variations in the isotopic composition of ocean water (an equilibrium effect). As such, the tests of foraminifera act as discrete tracer grains which accumulate on the seafloor. Were it not for the burrowing activity of benthic organisms, these tracer grains would be buried and preserved at their original stratigraphic levels. However, the stratigraphic distributions of microtektite particles in cores have demonstrated that bioturbation tends to mix particles both downward and upward in the sediment column [16]. The coupled action of bioturbation and sediment accumulation mixes the level of maximum tracer abundance downward into the sediment column and carries decreasing amounts of the tracer upward into the accumulating sediments.

Several sediment mixing models have been developed to correct for the mixing effects of bioturbation [12-15,17]. A feature common to all of these models is that the amplitude of the downward mixing is determined by the depth chosen for the well-mixed layer. The extent of downward mixing is largely restricted to the uppermost $\sim 8$ $\mathrm{cm}$ of sediment, which radiocarbon studies indicate is the maximum depth of the well-mixed bioturbation zone [14,18]. North Atlantic sediment radiocarbon profiles suggest a shallower mixed-layer depth [19], so the choice of $8 \mathrm{~cm}$ represents an upper limit for the stratigraphic displacement effect due to bioturbation. Sedimentation rate and mixed-layer depth are the key variables, although several of the more complex models have also included variations in mixing intensity, tracer abundance and supply input function (impulse or continuous) [13-15]. Impulse event tracers such as ash or microtektite particles will be mixed as a single function of sedimentation rate, whereas continuous function tracers such as the isotopic composition of foraminifera are dependent upon both sedimentation rate and the period of the supply function. Bard et al. [15] have shown that mixing displacement of continuous tracers decreases as the period of the supply function increases. Peng and Broecker [14] also discuss the importance of the coupled effects of dissolution and bioturbation on the observed abundance of foraminifera; this effect can be highly significant but it is difficult to recognize and harder to quantify. Despite the inherent complexity of bioturbation, the direction of the displacement effect (downwards) and its approximate maximum amplitude $(\sim 8 \mathrm{~cm})$ are well-constrained.

For the purposes of this study, a relationship is needed which corrects for the downward mixing displacement as a function of sedimentation rate $[13,15]$. We use the Bard et al. [15] mixing model because it specifically addresses the effects of mixing on continuous tracers and because it estimates the degree to which a periodically-varying tracer, 
such as isotopic data, will be phase-shifted due to bioturbation. The following deconvolution equation "unmixes" an isotopic record to its original prebioturbated depth ( $\mathrm{d} z=$ original-mixed depth; in $\mathrm{cm}$ ):

$$
\begin{aligned}
& \mathrm{d} z=\frac{L R}{2 \pi} \tan ^{-1}\left[\frac{2 \pi H}{R L}\right]-H \\
& \mathrm{~d} z=3.18 R \tan ^{-1}\left[\frac{2.51}{R}\right]-8.0
\end{aligned}
$$

Here, $R$ is the sedimentation rate $\left(\mathrm{cm} \mathrm{kyr}^{-1}\right)$, $H$ is the depth of the mixed layer $(8 \mathrm{~cm})$ and $L$ is the period of the tracer input function. The Bard et al. [15] "unmixing" model assumes that the supply of tracer grains to the sediment surface varies at some uniform period $L$. A 20,000-year input function period was chosen because it is roughly equivalent to the period of the Stage 19.1 oxygen isotopic event used in this study. Figure 1 illustrates the effect of bioturbation on the position of a marker bed: mixing tends to displace markers downward in low-sedimentation rate sequences, but this displacement approaches zero with increasing sedimentation rate. The total amplitude of this effect $(\sim 8 \mathrm{~cm})$ is equivalent to the mixed layer depth suggested by the radiocarbon data.

\section{Core data and methods}

The stratigraphic positions of oxygen isotopic Stage 19.1 and the boundary between the Brunhes and Matuyama Chronozones (B/M) were determined for eight cores with high-quality isotopic and paleomagnetic data, representing a range of

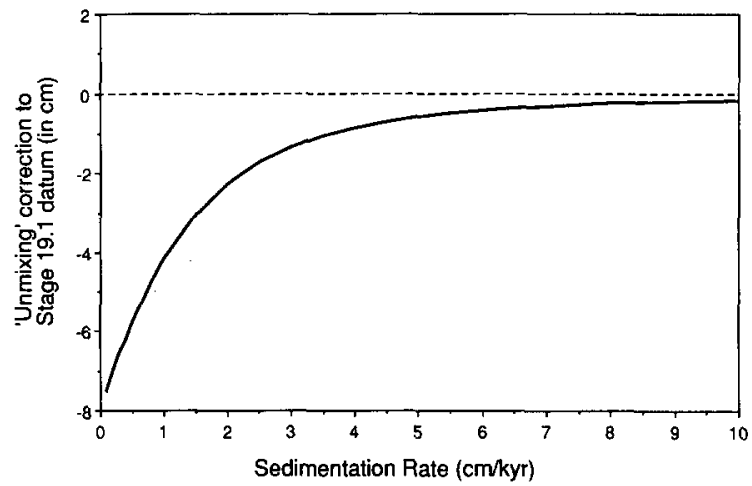

Fig. 1. Stratigraphic correction for the effect of bioturbation on periodically-varying particulate sedimentary tracers (such as the isotopic composition of foraminifera) using the unmixing model of Bard et al. [15]. The model assumes a $20 \mathrm{kyr}$ tracer input periodicity (roughly equivalent to isotopic Stage 19.1) and very rapid mixing rates. The total amplitude of this effect is set by the depth of the well-mixed layer selected for the model, which radiocarbon studies suggest is $\sim 8 \mathrm{~cm}$ [18].

sedimentation rates from 0.99 to $8.64 \mathrm{~cm} \mathrm{kyr}^{-1}$ (Table 1). Because Stage 19.1 is a well-defined isotopic event which is stratigraphically adjacent to the B/M boundary (see Fig. 2), it is ideal for the purposes of this study. Carbonate percent data were used for Site 609 since isotope data were unavailable; however, Ruddiman et al. [20] have indicated that the carbonate and isotope data for nearby Site 607 are correlative. Sedimentation rates were calculated by dividing the depth of the $\mathrm{B} / \mathrm{M}$ boundary by its age (730 kyr; [21]), except for Site 609 , which has a notably higher sedimentation rate for the late Matuyama-early Brunhes interval [22].

TABLE 1

Eight deep-sea sediment cores with high-quality isotopic and paleomagnetic data

\begin{tabular}{llll}
\hline Core/site & $\begin{array}{l}\text { Location } \\
(\mathrm{m})\end{array}$ & $\begin{array}{l}\text { Water depth } \\
(\mathrm{m})\end{array}$ & $\begin{array}{l}\text { Avg. accum. rate } \\
\left(\mathrm{cm} \mathrm{kyr}^{-1}\right)\end{array}$ \\
\hline V28-239 & E. Eq. Pacific & 3490 & 0.99 \\
V28-238 & E. Eq. Pacific & 3120 & 1.64 \\
S552A & N. Atlantic & 2311 & 2.00 \\
S502B(COMP) & Caribbean & 3051 & 2.22 \\
S607(COMP) & N. Atlantic & 3427 & 4.33 \\
S610 & N. Atlantic & 2417 & 5.78 \\
S609(COMP) & N. Atlantic & 3883 & 8.20 \\
S646A(COMP) & N. Atlantic & 3451 & 8.64 \\
\hline
\end{tabular}

The COMP suffix indicates that depths are composite depths. 
TP607

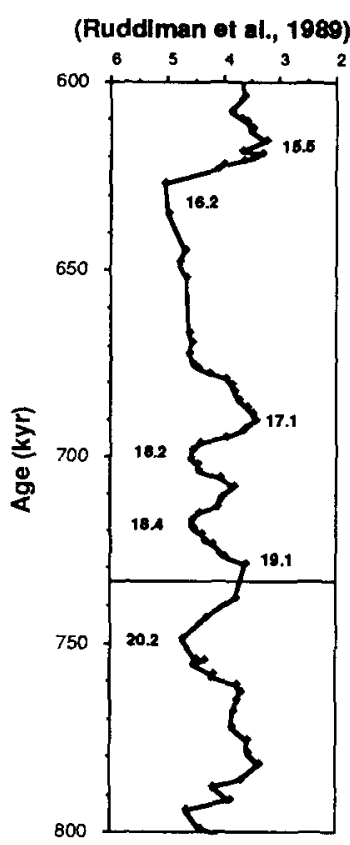

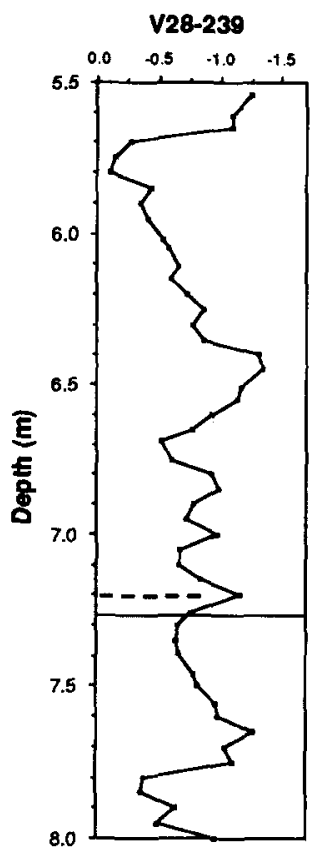
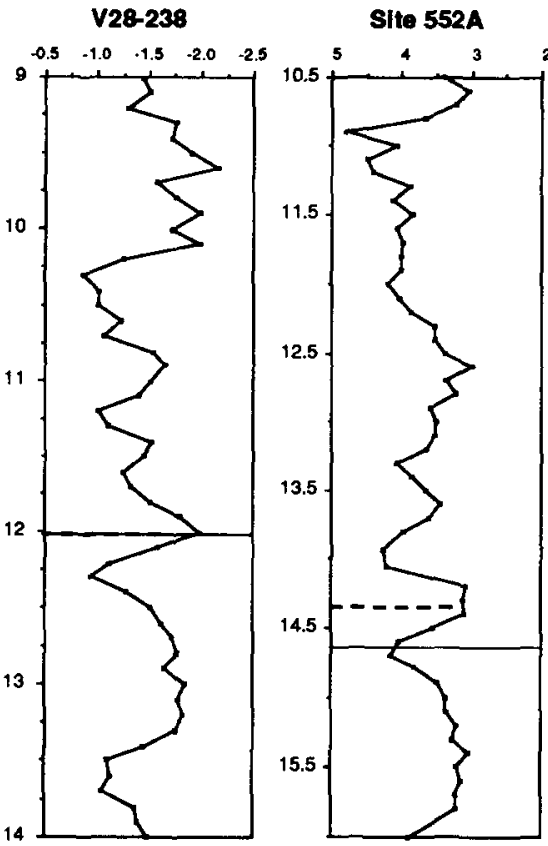

Site 502 COMP

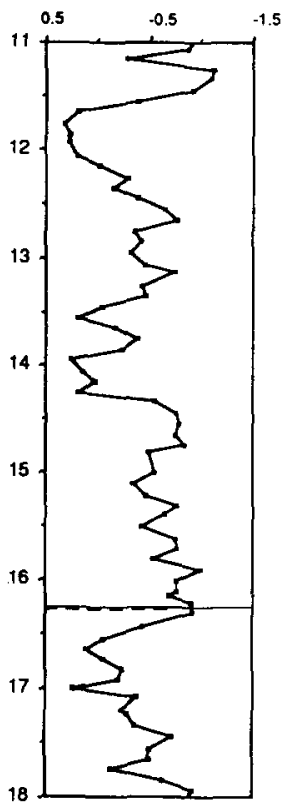

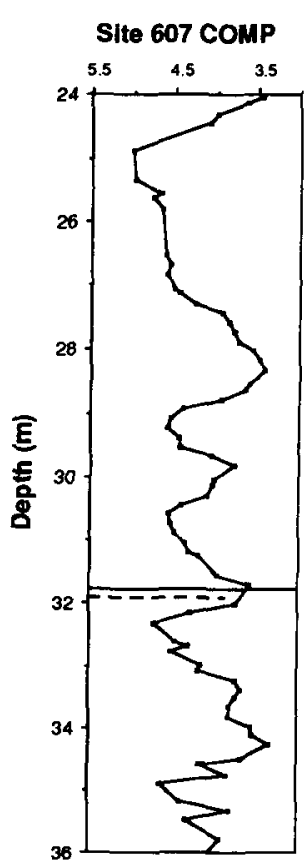
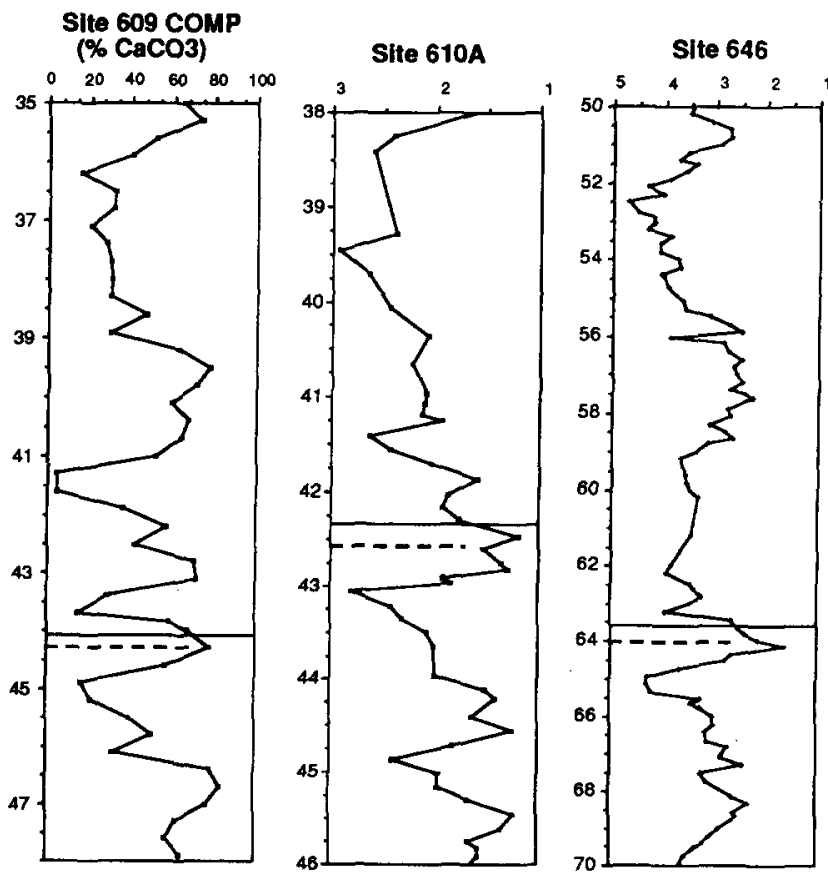

\footnotetext{
Stage 19.1 position

B/M reversal position
}

Fig. 2. Oxygen isotopic data and the positions of the Brunhes/Matuyama Chron reversal for eight cores. The midpoint datum of Stage 19.1 is is indicated by a short dashed line, and the B/M boundary is indicated by a solid horizontal line. The "TP607" isotopic time scale is shown for reference [20]. The core data are arranged so that sedimentation rate increases from upper left to lower right. 
TABLE 2

Statistical data of eight deep-sea sediment cores

\begin{tabular}{|c|c|c|c|c|c|c|c|}
\hline Core/site & $\begin{array}{l}\text { B/M depth } \\
\text { (m) }\end{array}$ & $\begin{array}{l}\text { Error } \\
\text { (m) }\end{array}$ & $\begin{array}{l}\text { Stage } 19.1 \text { depth } \\
\text { (m) }\end{array}$ & $\begin{array}{l}\text { Error } \\
(\mathrm{m})\end{array}$ & $\begin{array}{l}\Delta z(B / M, \text { Stage 19.1) } \\
(\mathrm{m})\end{array}$ & $\begin{array}{l}\text { "Unmixed" } \Delta z \\
\text { (m) }\end{array}$ & $\begin{array}{l}\Sigma \text { error } \\
\text { (m) }\end{array}$ \\
\hline V28-239 & 7.27 & \pm 0.02 & 7.20 & \pm 0.03 & +0.07 & +0.11 & \pm 0.05 \\
\hline V28-238 & 12.01 & 0.03 & 12.01 & 0.05 & 0.00 & +0.03 & 0.08 \\
\hline S552A & 14.67 & 0.04 & 14.38 & 0.05 & +0.29 & +0.31 & 0.09 \\
\hline S502B & 16.25 & 0.05 & 16.27 & 0.05 & -0.02 & 0.00 & 0.10 \\
\hline S607 & 31.77 & 0.01 & 31.94 & 0.07 & -0.17 & -0.16 & 0.08 \\
\hline S610 & 42.35 & 0.17 & 42.57 & 0.05 & -0.22 & -0.21 & 0.22 \\
\hline S609 & 44.06 & 0.08 & 44.29 & 0.07 & -0.23 & -0.23 & 0.15 \\
\hline S646A & 63.64 & 0.79 & 64.05 & 0.10 & -0.41 & -0.41 & 0.89 \\
\hline
\end{tabular}

Data references: V28-239, [45]; V28-239, [25]; S552A, [46, and D. Kent, unpubl. data]; S502B, [47,48]; S607, [20,22]; S610, [E. Jansen, unpubl. data; 22]; S609, [20,22]; S646A, [49,50].

Several criteria were established for determining the relative positions of the isotopic and paleomagnetic boundaries. The stratigraphic position of the $\mathrm{B} / \mathrm{M}$ boundary was determined as the midpoint between the closest samples characterized by stable NRM directions with opposite (reversed and normal) polarity. The $\mathrm{B} / \mathrm{M}$ transition occurred within one sample interval (i.e. between two adjacent samples) for all cores except at Site 646A. The error associated with the $\mathrm{B} / \mathrm{M}$ reversal depth was estimated using \pm one-half sample interval. High-resolution paleomagnetic studies have demonstrated that the directional component of a magnetic field reversal is completed in 4-10 kyr [23]; for a $10 \mathrm{~cm} \mathrm{kyr}^{-1}$ core, this would translate to an uncertainty in the boundary pick ranging between 40 and $100 \mathrm{~cm}$ (i.e. $\pm 20-50 \mathrm{~cm}$ ). Such transitional behavior was only significant at Site $646 \mathrm{~A}$, however, and the uncertainty associated with this datum was large (Table 2; [24], B. Clement, pers. commun.).

The depth of the oxygen isotope minimum associated with Stage 19.1 was determined by selecting the midpoint of the low-frequency wave $(\sim 20$ kyr) defining Stage 19.1. This was deemed more reliable than choosing the absolute lowest value, because oxygen isotopic analytical errors are typically $0.1-0.2 \%$. This procedure was unambiguous for all cores except Site 502B. The error associated with the Stage 19.1 datum was estimated using \pm one-half sample interval. The difference in depth between the B/M boundary and Stage 19.1 (in $\mathrm{cm})$ was defined as $\Delta z$, and its associated error was estimated by summing the $B / M$ and isotopic errors. The data and references for each of the eight cores are listed in Table 2.

\section{Results}

The Stage 19.1 and B/M reversal level for each of the eight cores are shown in Fig. 2, with the isotope data compared to the "TP607" time scale of Ruddiman et al. [20]. With increasing sedimentation rate, the $B / M$ boundary appears to move upsection relative to the Stage 19.1 isotopic level, as demonstrated by the plot of $\Delta z$ (with its associated error) versus sedimentation rate (Fig. 3a).

The amplitude of the $\Delta z$ trend shown in Fig. 3a reflects the combined effects of PDRM lock-in depth variability (on the reversal datums) and bioturbation (on the isotopic datums). The stratigraphic effects of bioturbation must be removed to isolate the PDRM signal. This is accomplished by applying eqn. (1) (shown graphically in Fig. 1) to the isotopic datums for each of the eight cores. The "unmixed" Stage 19.1 isotopic datums should be virtually isochronous because they have been corrected to their original depositional levels and the oxygen isotopic response time of the ocean is rapid, less than $1 \mathrm{kyr}[15,25]$. The unmixing correction actually increases the $\Delta z$ values, because the isotopic datum becomes shallower after the unmixing correction (Fig. 3b, Table 2). The "unmixed" $\Delta z$ values shown in Fig. $3 b$ should reflect the actual amplitude of the PDRM lock-in depth variability with sedimentation rate, provided that the unmixing model assumptions of an $8 \mathrm{~cm}$ mixed 


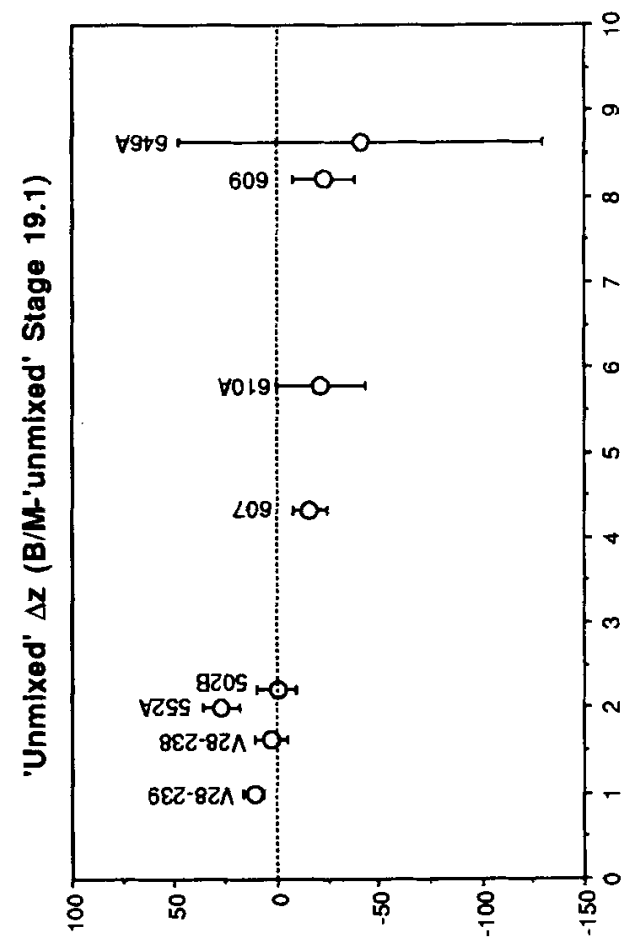

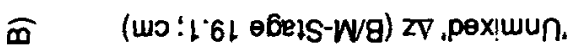

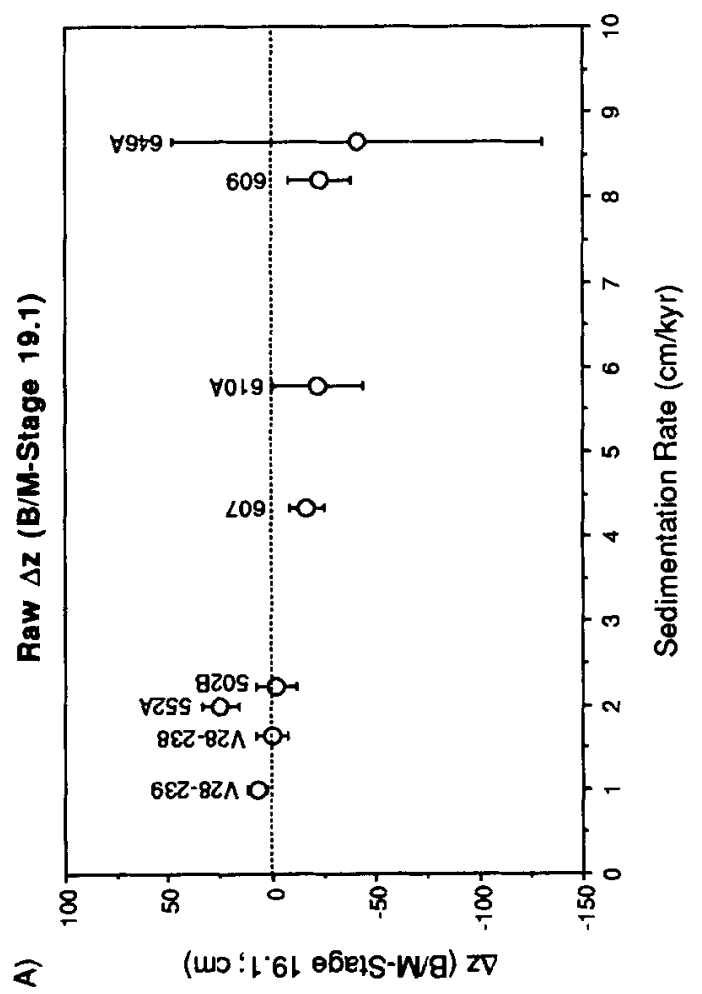

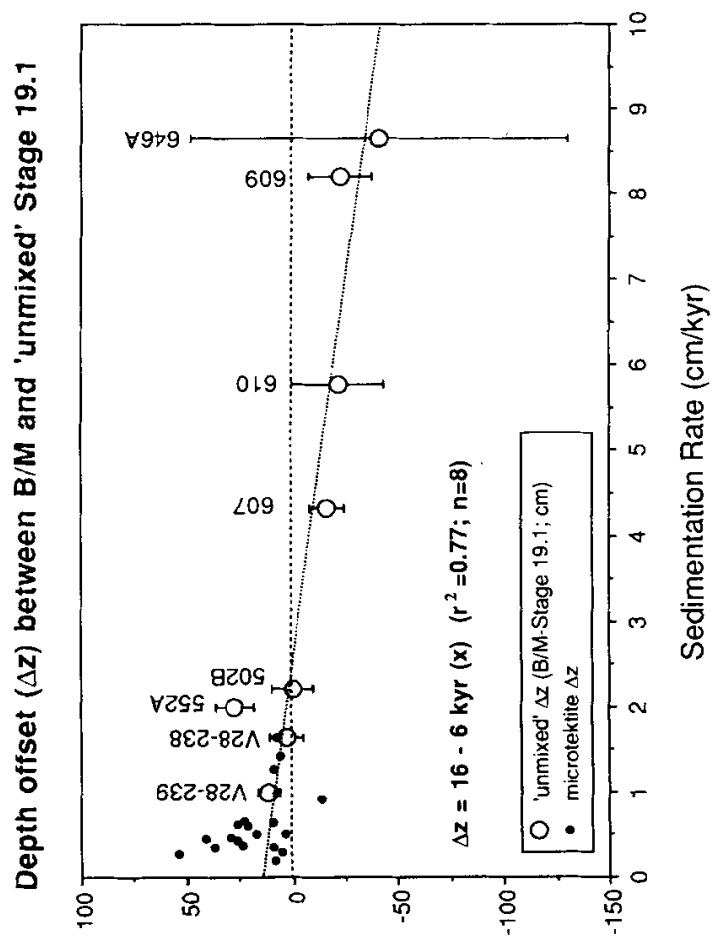

ธ

(แง !เ・6เ อ68เS-W/g) $z \nabla$

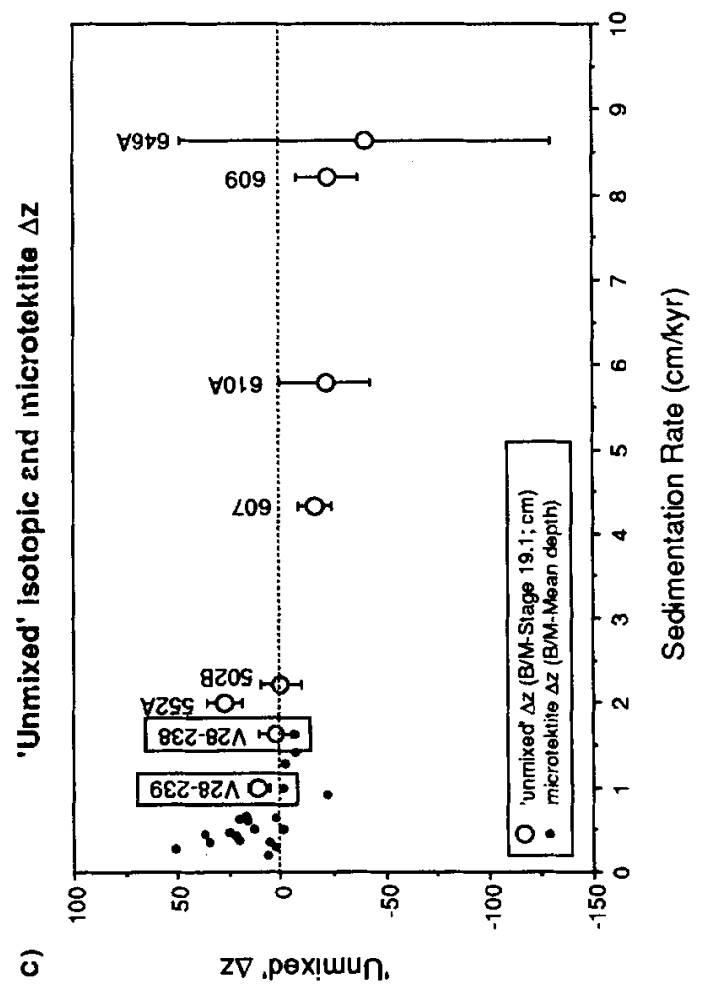


layer depth and uniform mixing intensity are valid [15].

\subsection{Inclusion of Burns' [1989] microtektite data}

Results from a recent paper by Burns [1] may also be added to the data shown in Fig. 3b. In this study, Burns compared the relative positions of the $\mathrm{B} / \mathrm{M}$ boundary and the Australasian microtektite layer in twenty low sedimentation rate cores $\left(0.19-1.64 \mathrm{~cm} \mathrm{kyr}^{-1}\right)$ to investigate the proposed synchroneity of the two events. These data are particularly useful for our study because they represent low sedimentation rate cores which generally have too few foraminifera for isotopic analyses. The isotopic and microtektite datums are comparable data sets since both are particulate tracers susceptible to benthic mixing. However, the Bard et al. [15] unmixing relation cannot be used to correct these data for bioturbation because it was derived for continuous (not impulse) tracers. Rather, the original depth of deposition for impulse tracers such as microtektite or ash particles can be obtained by determining the center of mass (weighted mean depth) of the microtektite abundance profile $[1,13,19]$; these data are presented in the original Burns [1] reference. The microtektite $\Delta z$ values were calculated $(\Delta z=\mathrm{B} / \mathrm{M}$-weighted mean microtektite abundance depth) and these values are shown with the unmixed isotopic $\Delta z$ values in Fig. 3c. Two cores (V28-238 and V28-239) have both microtektite and isotopic datums and these can be used to combine the two data sets.
Because the isotopic and microtektite datums are adjusted for bioturbation, the two datums should represent separate isochronous lithostratigraphic horizons which are separated by some constant time offset. To combine the two datums, it is necessary to determine this time offset; the microtektite datums can then be shifted by the depth interval equivalent to the time offset (based on the sedimentation rate). The purpose of combining the two datums is to end up with one isochronous stratigraphic level (equivalent to the Stage 19.1 datum) in each of the cores.

In core V28-239 $\left(0.99 \mathrm{~cm} \mathrm{kyr}^{-1}\right)$, the microtektite datum at $728 \mathrm{~cm}$ is $12 \mathrm{~cm}$ below the unmixed Stage 19.1 midpoint at $716 \mathrm{~cm}( \pm 3 \mathrm{~cm})$. The $12 \mathrm{~cm}$ depth offset in this core is equivalent to $12 \pm 3 \mathrm{kyr}$ in time. In core V28-238 $(1.64 \mathrm{~cm}$ $\mathrm{kyr}^{-1}$ ), the microtektite datum occurs at $1208 \mathrm{~cm}$, which is $10 \mathrm{~cm}$ below the unmixed Stage 19.1 midpoint at $1198 \mathrm{~cm}( \pm 5 \mathrm{~cm})$. Here, the $10 \mathrm{~cm}$ offset is equivalent to $6 \pm 3 \mathrm{kyr}$. The age offsets between the microtektite and Stage 19.1 datums can be reconciled if an age offset of $9 \mathrm{kyr}( \pm 3$ $\mathrm{kyr}$ ) is used. Therefore, to adjust the microtektite datums given in Burns [1] to the Stage 19.1 datums, the microtektite datums must be shifted up by a depth interval equivalent to $9 \mathrm{kyr}$. The depth shift equivalent to $9 \mathrm{kyr}$ was calculated by multiplying the sedimentation rate of the core in question $(\mathrm{cm}$ $\mathrm{kyr}^{-1}$ ) by $9 \mathrm{kyr}$ and then subtracting this result from the respective microtektite depth datum. The $\Delta z$ values (B/M minus microtektite datum adjusted to Stage 19.1 level) were then recalculated; these data are shown in Fig. 3d.

Fig. 3. (A) Plot of the stratigraphic displacements $(\Delta z=\mathbf{B} / \mathrm{M}$, Stage 19.1 ; in $\mathrm{cm})$ between the Stage $19.1 \mathrm{mid}-\mathrm{point}$ and the B/M reversal positions as a function of sedimentation rate (circles). Error bars were determined by summing the isotopic and paleomagnetic datum errors, which are largely a function of sampling density. (B) Same data as in (A), except that the Stage 19.1 datums have been corrected for stratigraphic displacement due to bioturbation using the Bard et al. [15] unmixing model (see Fig. 1). Note that the trend is essentially unaffected by the unmixing correction. (C) Same data as in (B), except that Burns' [1] Australasian microtektite $\Delta z$ data have been included (dots). The microtektite $\Delta z$ data were calculated as B/M reversal minus mean microtektite mass abundance depth. Note that cores V28-239 and V28-238 (boxed) have both Stage 19.1 and microtektite datums. (D) The dependence of $\Delta z$ (the B/M reversal minus the "unmixed" Stage 19.1 depth) as a function of sedimentation rate (circles). Burns' [1] microtektite data (dots) have been shifted so that they are equivalent to the Stage 19.1 level (see text). Because the isotopic (and microtektite) data have been corrected for bioturbation, the stratigraphic horizon they represent is equivalent to an isochronous horizon. Hence, the linear $\Delta z$ trend with sedimentation rate reflects both the age offset between the $B / M$ and isotopic datums and the depth at which the remanence is preserved. The regression equation indicates that the interglacial Stage 19.1 datum occurs $6 \pm 2$ $\mathrm{kyr}$ before the $\mathrm{B} / \mathrm{M}$ reversal, and that the reversal is acquired $\sim 16 \mathrm{~cm}$ below the sediment surface. Note that the $\Delta z$ data below $1 \mathrm{~cm}$ $\mathrm{kyr}^{-1}$ deviate significantly from the linear trend, indicating that remanence is acquired at unusually deep levels in these sediments. 


\section{Discussion}

Several features in Fig. 3d identify important relationships between the paleomagnetic and isotopic stratigraphies: (1) the direction, amplitude and general linearity of the $\Delta z$ trend $(\Delta z$ decreases with increasing sedimentation rate with a total amplitude of $\sim 70 \mathrm{~cm}$ ); (2) the positive ordinate and abcissa intercepts; and (3) the large deviation from linearity of the $\Delta z$ values from very low sedimentation rate cores. We argue that these features can only be reconciled if PDRM is acquired $\sim 16 \mathrm{~cm}$ below the sediment surface and if the $B / M$ reversal occurs $6 \mathrm{kyr}$ after the Stage 19.1 isotopic datum. Additionally, we suggest that PDRM is acquired at anomalously deep levels in very low accumulation rate sediments $(<1 \mathrm{~cm}$ $\mathrm{kyr}^{-1}$ ).

Because the Stage 19.1 isotopic (and microtektite) datums have been adjusted for bioturbation, the stratigraphic level they represent should be conceptually equivalent to an isochronous depositional horizon. However, the $B / M$ reversal depths cannot be so simply interpreted. Although the polarity reversal itself is effectively instantaneous over the surface of the globe, its preservation in sediments occurs at some unknown depth below the sediment surface and below the wellmixed zone. Hence, when the $\mathrm{B} / \mathrm{M}$ reversal depths are compared to the Stage 19.1 depths, the relative depth offsets $(\Delta z)$ should reflect both the isochroneity of the reversal itself and the depth at which the remanence was acquired. These two components can be isolated by plotting $\Delta z$ as a function of sedimentation rate (Fig. 3d).

\subsection{Age offset between the $B / M$ and Stage 19.1 datums and the depth of PDRM acquisition}

The age offset between the B/M and Stage 19.1 datums can be determined from the slope of the line suggested by the data; the depth of remanence acquisition is equivalent to the $\Delta z$ intercept value. A steeper (shallower) slope would indicate greater (lesser) time separation of the $\mathrm{B} / \mathrm{M}$ and Stage 19.1 isochrons; zero slope would indicate that the two datums are coeval. Similarly, the positive $\Delta z$ intercept value demonstrates that PDRM is acquired at some depth below the sedi- ment surface; a zero-intercept would indicate that PDRM is acquired at the sediment surface. The magnitude of the age offset and the depth of PDRM acquisition can be estimated from the coefficients of a linear regression fit to the data. The following equation was determined from the isotopic $\Delta z$ values which have sedimentation rates ranging from 0.99 to $8.64 \mathrm{~cm} \mathrm{kyr}^{-1}$ :

$$
\begin{gathered}
\Delta z=16-6 \mathrm{kyr} \text { (sedimentation rate); } \\
\left(r^{2}=0.77 ; n=8\right)
\end{gathered}
$$

Equation (2) demonstrates that most of the observed $\Delta z$ variance with sedimentation rate can be explained if the post-depositional remanence is acquired $\sim 16 \mathrm{~cm}$ below the sediment surface, and if the B/M polarity reversal occurs $6 \mathrm{kyr}( \pm 2$ kyr, 95\% confidence interval) after the Stage 19.1 isotopic datum. The regression line is shown in Fig. 3d. The Site 552A $\Delta z$ datum deviates appreciably from the linear trend, indicating that the $\mathrm{B} / \mathrm{M}$ boundary is significantly deeper than would be predicted from the model. This may be attributable to variations in the consolidation factors which affect the depth of PDRM acquisition. In additions, the microtektite $\Delta z$ values (dots) with sedimentation rates greater than $1 \mathrm{~cm} \mathrm{kyr}^{-1}$ fall along this same trend; inclusion of these four data points does not significantly alter the regression coefficients, but the $r^{2}$ value increases to 0.81 . As noted by Burns [1], the very low sedimentation rate $\Delta z$ data $\left(<1 \mathrm{~cm} \mathrm{kyr}^{-1}\right)$ depart significantly from this general linearity, and the significance of this will be discussed later.

Figures $4 a-c$ show a diagrammatic representation of the sequence of events summarized in the model represented by eqn. (2). Tests of foraminifera which calcified in the interglacial Stage 19.1 ocean are first deposited on the seafloor; after correcting for the mixing effects of bioturbation, this layer defines an isochronous depositional horizon (Fig. 4a). Sediments continue to accumulate (at different sedimentation rates) for about 6 kyr (solid line in Fig. 4b). At this point, the directional component of the Brunhes-Matuyama polarity reversal is completed (dashed line, Fig. 4b). In the sediments, however, the reversal is acquired at a sub-surface depth of about $16 \mathrm{~cm}$ below the surface (Fig. 4c). As shown in Fig. 4d, this model accounts for most $(\sim 80 \%)$ of the ob- 


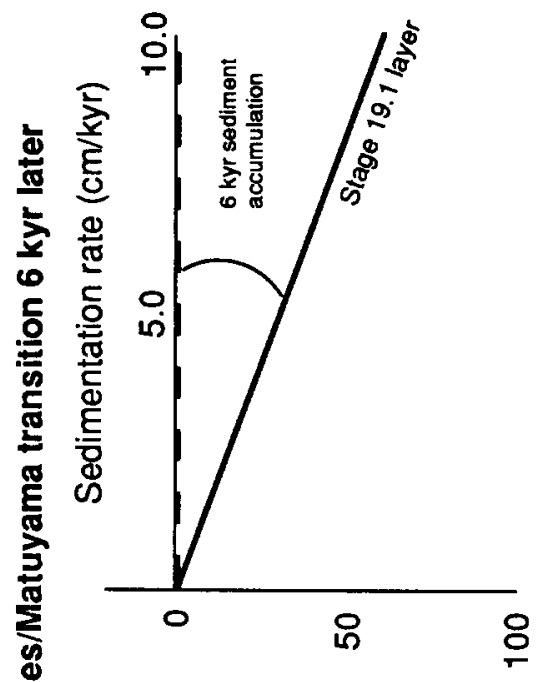

(wo) $41 \mathrm{~d}$ व

ติ

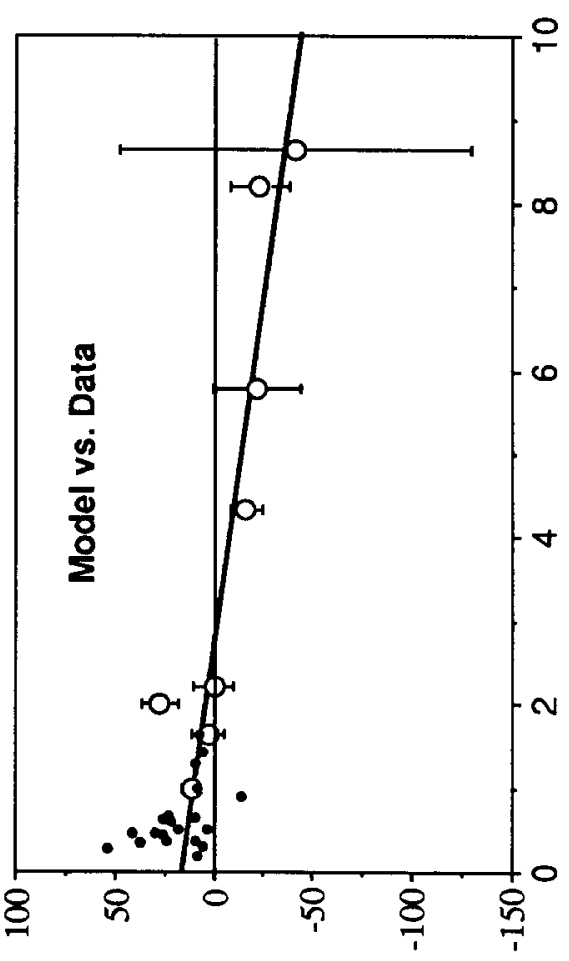

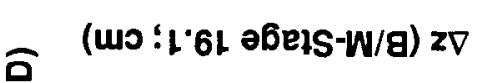

$\sum_{\substack{0 \\ \infty}}$

일

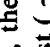

올

突

हुํํㄹ

工

零

E

응

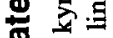

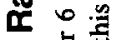

o。

菏

远

总言

응

๗

원

\&

文泀

密

는

婴

동

동는
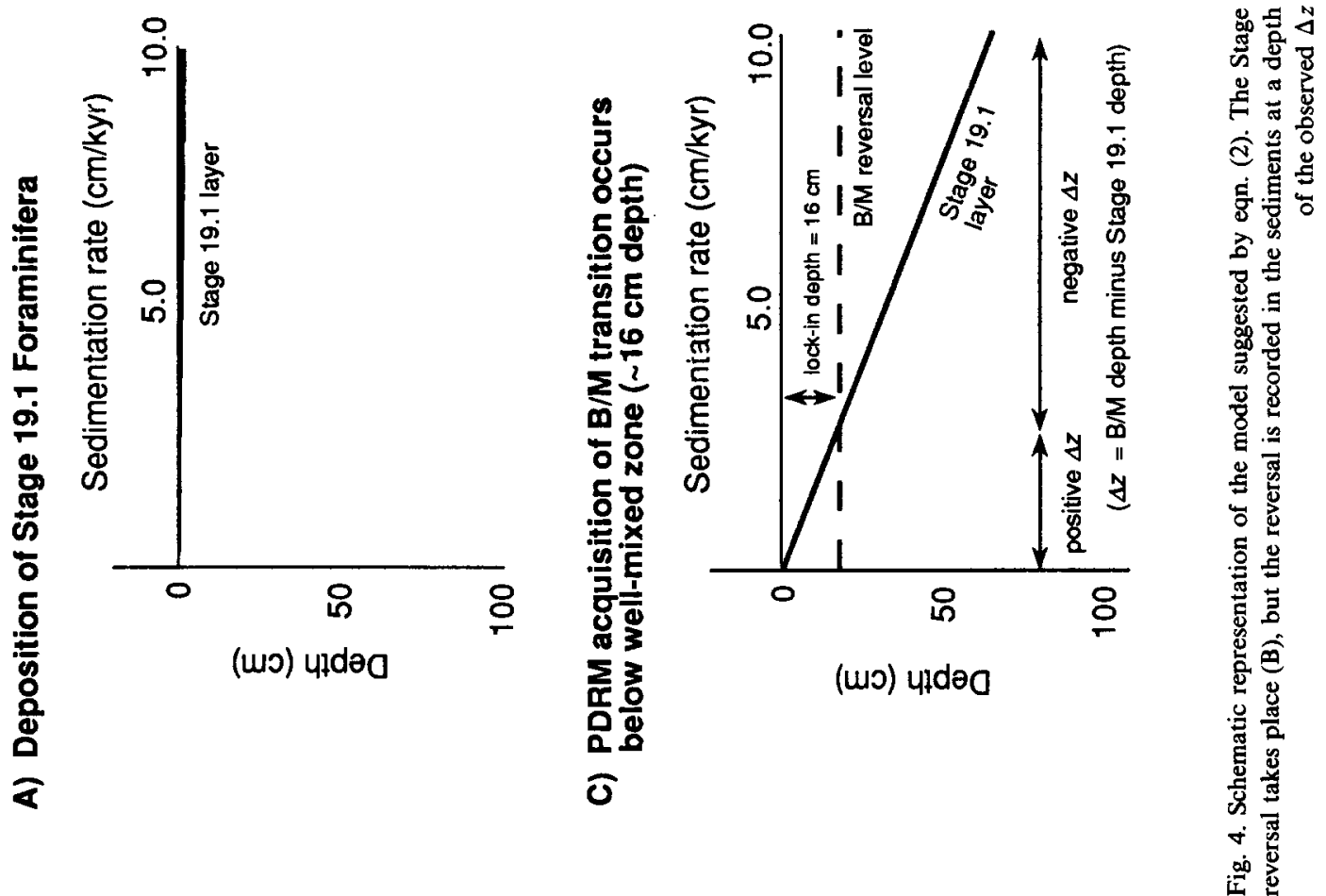
served depth variability between the Stage 19.1 isotopic and paleomagnetic stratigraphies.

Our estimate for the PDRM lock-in depth lies within the broad constraints of other published estimates. The production of ${ }^{10} \mathrm{Be}$ in the upper atmosphere is inversely proportional to the Earth's magnetic field intensity. When the field intensity is reduced during reversals, ${ }^{10} \mathrm{Be}$ production is enhanced and this is ultimately recorded in sediments. The intensity reduction and increased ${ }^{10} \mathrm{Be}$ levels (relative to stable ${ }^{9} \mathrm{Be}$ ) associated with a field reversal should be synchronous; however, Raisbeck et al. [11] noted that the B/M boundary was displaced $\sim 10-15 \mathrm{~cm}$ below the maximum ${ }^{10}$ Be level in core V15-68 $\left(\sim 2.5 \mathrm{~cm} \mathrm{kyr}^{-1}\right)$ and attributed this to PDRM acquisition at depth. Similarly, Aylmer et al. [26] presented preliminary results from Site $609\left(8.2 \mathrm{~cm} \mathrm{kyr}^{-1}\right)$ where the $\mathrm{B} / \mathrm{M}$ transition was displaced $\sim 30 \mathrm{~cm}$ below the

${ }^{10} \mathrm{Be}$ maximum. Unfortunately, a firmer estimate for the lock-in depth cannot be obtained from these data until problems with sampling resolution and ${ }^{10} \mathrm{Be}$ normalization are resolved [27]. This $10-30 \mathrm{~cm}$ range in PDRM lock-in depth is generally consistent with estimates from other workers $[6,7,10]$.

\subsection{Deep PDRM acquisition in low accumulation rate sediments}

The broad range of sedimentation rates represented by our cores provides the required "leverage" for defining the $16 \mathrm{~cm}$ nominal depth of PDRM acquisition in higher sedimentation rate cores. However, Burns [1] has noted that low accumulation rate sediments have unusually deep PDRM acquisition depths, based on the depth offsets between the Australasian microtektite layer and the $\mathrm{B} / \mathrm{M}$ boundary in low sedimentation rate cores. By "bootstrapping" his data with our higher sedimentation rate data, our results support his important finding: PDRM acquisition occurs at relatively deep levels in low sedimentation rate cores.

Burns [1] has suggested that the relatively deep PDRM acquisition in low accumulation rate sediments could be attributed to the relatively higher clay content, and hence higher porosity, of lower accumulation rate sediments. We contend that deep PDRM acquisition may be attributable to time-dependent consolidation processes in clayrich sediments, rather than clay content itself. Experimental [4-6] and theoretical [6-8] considerations have identified consolidation as the important variable affecting remanence acquisition. The rigidity, or structural strength, of clay-rich deep-sea sediments is governed by cohesion which is the result of electrical (Van der Waal and Coulombic) interparticle forces [28]. Given sufficient time (i.e. low loading rates), these interparticle forces act to increase sediment structural strength through the development of rigid "cardhouse" or flocculated structure which maximizes the number of interparticle contacts [29].

This time-dependent phenomenon has been observed in natural sediments [31-35] as well as under experimental conditions [36-38]. These studies demonstrate that sediment structural strength increases with decreasing sedimentation rate (i.e. surface sediment residence time). The increased structural strength of low accumulation rate sediments inhibits the initial reduction in porosity associated with early burial-compaction in the uppermost meter of the sediment column [39-42]. In terms of geotechnical properties, this is manifested by relatively low porosity reduction gradients in the uppermost sediments. This is commonly termed "apparent underconsolidation" because the porosity gradient is lower than that which would be expected from the overburden load of the overlying sediments.

The relevance of this mechanism to post-depositional detrital remanent magnetism is that lower deposition rate sediments would be expected to acquire their magnetic remanence relatively deep in the sediment column compared to higher deposition rate sediments, and this is what is observed. While the interaction between consolidation and sedimentation rate is apparently a first-order relation, other variables such as grain size, clay mineralogy and siliceous and carbonate microfossil content play important, and often reinforcing, roles in the relationship between sediment structural strength and sedimentation rate [43].

\subsection{Chronostratigraphy of the $B / M$ reversal, Stage 19.1 and the Australasian microtektite layer}

An important result of this study is that we are able to estimate the relative age offsets for the 


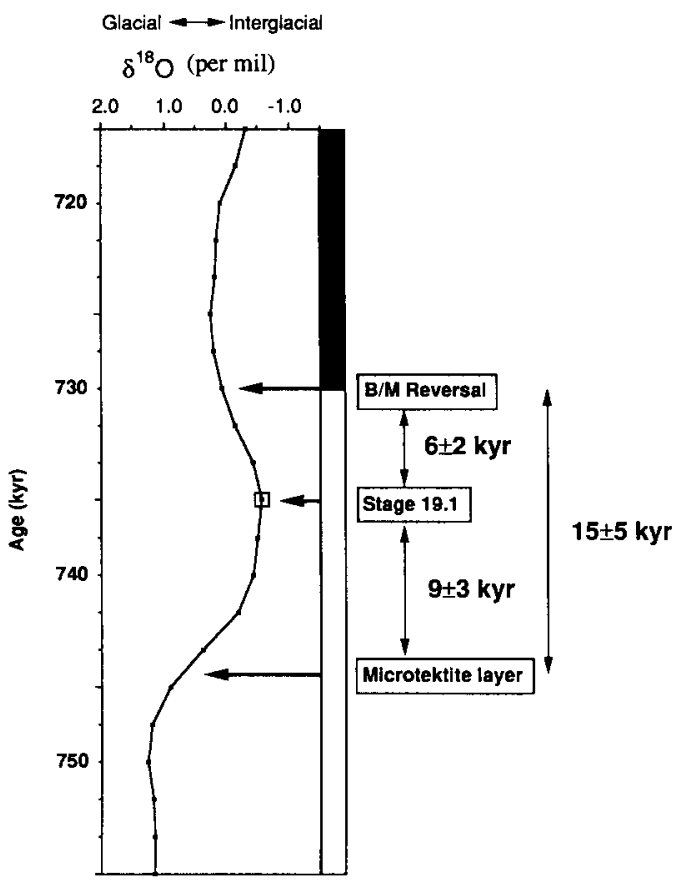

Fig. 5. Graphic representation of the relative temporal offsets between the Brunhes-Matuyama reversal, Stage 19.1 isotopic event (corrected for bioturbation) and the Australasian microtektite strewnfield layer (also corrected for bioturbation).

B/M reversal, Stage 19.1 and microtektite datums (Fig. 5). As discussed earlier, the Stage 19.1 isotopic datum occurs $9 \pm 3 \mathrm{kyr}$ after the deposition of the Australasian microtektite layer in cores V28-238 and V28-239. From eqn. (2) the B/M reversal occurs $6 \pm 2 \mathrm{kyr}$ after the Stage 19.1 datum. Hence, the microtektite layer preceeds the $\mathrm{B} / \mathrm{M}$ reversal by $15 \pm 5 \mathrm{kyr}$, in good agreement with Burns' [1] estimate of $\sim 12$ kyr based on low accumulation rate cores.

Our analyses demonstrate that these age offsets are real (within their estimated errors) and that the different datums are not coeval. In particular, the Australasian microtektite datum significantly preceeds interglacial Stage 19.1 and the $B / M$ reversal, so that any mechanism which causally links these datums should account for these temporal offsets. A mechanism has been proposed [44] whereby a hypothetical bolide impact leads to global cooling and the redistribution of ocean water as polar ice alters the crust-mantle rotation rates and ultimately results in a geomagnetic excursion or reversal. Our results (Fig. 5) would suggest that the $\mathrm{B} / \mathrm{M}$ reversal is preceeded by an interglacial, not glacial, climate. These data provide important contraints for geophysical models which attempt to link geomagnetic reversals with glacial-interglacial climate change or impact events.

\section{Summary}

In this study we have focused on the relative stratigraphic offsets among oxygen isotopic Stage 19.1, the Australasian microtektite layer, and the Brunhes-Matuyama Chronozone reversal, as well as their relationship with sedimentation rate. Detailed oxygen isotopic and paleomagnetic data from eight cores representing a range of sedimentation rates from 0.99 to $8.64 \mathrm{~cm} \mathrm{kyr}^{-1}$ were used to extend the initial microtektite results of Burns [1]. Together, these data can be used to examine the temporal relationships among these datums and the natural variability of the acquisition depth of post-depositional remanent magnetization. Particulate sedimentary event tracers such as the Stage 19.1 foraminifera and microtektites represent isochronous depositional horizons which are subsequently mixed and displaced by bioturbation. Hence, when the $\mathrm{B} / \mathrm{M}$ reversal depths are compared to the bioturbation-corrected Stage 19.1 depths, their depth offsets $(\Delta z)$ reflect both the isochroneity of the reversal itself and the depth at which the remanence was acquired. These two components are isolated by plotting $\Delta z$ as a function of sedimentation rate.

(1) There is an approximately linear trend between $\Delta z$ (calculated as $\mathrm{B} / \mathrm{M}$ minus unmixed Stage 19.1 depth) and sedimentation rate. The slope of the trend demonstrates that the $B / M$ reversal occurs $6 \pm 2$ kyr after the Stage 19.1 isotopic event. The positive $\Delta z$ intercept indicates that remanence is acquired $\sim 16 \mathrm{~cm}$ below the sediment surface. A linear model with these characteristics accounts for $-80 \%$ of the $\Delta z$ variability with sedimentation rate.

(2) At very low sedimentation rates $(<1 \mathrm{~cm}$ $\mathrm{kyr}^{-1}$ ), the $\Delta z$ values are considerably higher than would be expected based on the linear model. These data demonstrate that PDRM acquisition occurs at relatively deeper levels $(30-50 \mathrm{~cm})$ for low accumulation rate sediments. The geotechnical literature indicates that the relatively deep 
PDRM acquisition depth may be attributable to the unusual physical properties of these sediments. Under low deposition rates, sediments have sufficient time to develop enhanced interparticle rigidity (structural strength) which inhibits early compaction and, hence, PDRM acquisition.

(3) These data can be used to establish relative temporal relationships between the isotopic, microtektite and paleomagnetic datums. The Australasian microtektite layer occurs $9 \pm 3 \mathrm{kyr}$ prior to the Stage 19.1 isotopic event, and the Stage 19.1 event occurs $6 \pm 2 \mathrm{kyr}$ prior to the $\mathrm{B} / \mathrm{M}$ reversal. These data demonstrate that the Australasian microtektite strewnfield was deposited $15 \pm 5 \mathrm{kyr}$ prior to the $\mathrm{B} / \mathrm{M}$ geomagnetic reversal.

\section{Acknowledgements}

We would like to thank E. Jansen, B. Clement, A. Aksu and F. Hall for allowing us to use their prepublished isotopic and paleomagnetic data from Sites 610 and 646. David Schneider, Edouard Bard, John Imbrie, Billy Glass and Chris Burns were very helpful in reviewing early versions of the manuscipt. Christina Ravelo provided helpful comments and suggestions, some of which have been included in the final manuscript. Helpful reviews were provided by Joe Kirschvink and Maureen Raymo. This is Lamont-Doherty Geological Observatory contribution 4600.

\section{References}

1 C.A. Burns, Timing between a large impact and a geomagnetic reversal and the depth of NRM acquisition in deep sea sediments, in: Geomagnetism and Paleomagnetism, F.J. Lowes et al., eds., pp. 253-261, 1989.

2 C.E. Barton and M.W. McElhinny, Detrital remanent magnetization in five slowly redeposited long cores of sediment. Geophys. Res. Lett. 6, 229-232, 1979.

3 E. Irving, Origin of the paleomagnetism of the Torridonian sandstone of north-west Scotland. Phil. Trans. R. Soc. London, A, 250, 100-110, 1957.

4 D.V. Kent, Post-depositional remanent magnetization in deep-sea sediment. Nature 246, 32-33, 1973.

5 R. Løvlie, Post-depositional remanent magnetization in a re-deposited deep-sea sediment. Earth Planet. Sci. Lett. 21, 315-320, 1974.

6 Y. Hamano, An experiment on the post-depositional remanent magnetization in artificial and natural sediments. Earth Planet. Sci. Lett. 51, 221-232, 1980.
$7 \mathrm{~K}$. Yaskawa, When did magnetization fix in in loose sediments? Conf. Late Cenozoic Magnetostratigr., Int. Union Geol. Sci., Tokyo, 1974.

8 C.R. Denham and A.D. Chave, Detrital remanent magnetization: Viscousity theory of the lock-in zone. J. Geophys. Res. 87, 7126-7130, 1982.

9 K.L. Verosub, Depositional and postdepositional processes in the magnetization of sediments. Rev. Geophys. Space Phys. 15, 129-143, 1977.

10 N. Niitusuma, Zone magnetization model and depth lag of NRM in deep-sea sediments. Rock Magn. Paleogeophys. 4 , 65-71, 1977.

11 G.M. Raisbeck, F. Yiou, D. Bourles and D.V. Kent, Evidence for an increase in cosmogenic ${ }^{10}$ Be during a geomagnetic reversal. Nature 315, 315-317, 1985.

12 W.H. Berger, R.F. Johnson and J.S. Killingly, "Unmixing" of the deep-sea record and the deglacial meltwater spike. Nature 269, 661-663, 1977.

13 N.L. Guinasso and D.R. Schink, Quantitative estimates of biological mixing rates in abyssal sediments. J. Geophys. Res. 80, 3032-3043, 1975.

14 T.-H. Peng and W.S. Broecker, The impacts of bioturbation on the age difference between benthic and planktonic foraminifera in deep-sea sediments. Nucl. Instrum. Methodol. Phys. Res. B5, 346-352, 1984.

15 E. Bard, M. Arnold, J. Duprat, J. Moyes and J.-C. Duplessy, Reconstruction of the last deglaciation: Deconvolved records of O-18 profiles, micropaleontological variations and accelerator mass spectrometric 14-C dating. Clim. Dyn. 1, 101-112, 1987.

16 B.P. Glass, R.N. Baker, D. Storzer and G.A. Wagner, North American microtektites from the Caribbean Sea and their fission track age. Earth Planet. Sci. Lett. 19, 184-192, 1973.

17 W.H. Berger and G.R. Heath, Vertical mixing in pelagic sediments. J. Mar. Res. 26, 134-143, 1968.

18 T.-H. Peng, W.S. Broecker and W.H. Berger, Rates of benthic mixing in deep-sea sediment as determined by radioactive tracers. Quat. Res. 11, 141-149, 1979.

19 W.F. Ruddiman, G.A. Jones, T.-H. Peng, L.K. Glover, B.P. Glass and Liebertz, Tests for size dependency in deep-sea mixing. Sed. Geol. 25, 257-276, 1980.

20 W.F. Ruddiman, M.E. Raymo, D.G. Martinson, B.M. Clement and J. Backman, Pleistocene evolution of Northern Hemisphere climate. Paleoceanography (in press), 1989.

21 E.A. Mankinen and G.B. Dalrymple, Revised geomagnetic polarity timescale for the interval 0-5 m.y.b.p. J. Geophys. Res. 84, 615-625, 1979.

22 B. Clement and F. Robinson, The magnetostratigraphy of Leg 94 sediments, in: W. Ruddiman and R. Kidd et al., eds., Init. Rep. DSDP, 94, U.S. Gov. Print. Off., Washington D.C, 1985.

23 B. Clement and D.V. Kent, Latitudinal dependency of geomagnetic polarity transition durations. Nature 310 , 488-491, 1984.

24 B. Clement, F. Hall and R. Jarrard, The magnetostratigraphy of Ocean Drilling Program Leg 105 sediments, in: S.P. Srivastava and M. Arthur et al., eds., Proc. ODP, Init. Rep., 105, U.S. Gov. Print. Off., Washington, D.C, in press. 
25 N.J. Shackleton and N. Opdyke, Oxygen isotope and paleomagnetic stratigraphy of equatorial Pacific core V28238: Oxygen isotope temperatures and ice volumes on a $10^{5}$ to $10^{6}$ year scale. Quat. Res. 3, 39-55, 1973.

26 D. Aylmer, M. Herzog, G.F. Guyton, B. Clement, J, Klein and $\mathbf{R}$. Middleton, Beryllium-10 contents of sediments associated with the Matuyama-Brunhes geomagnetic reversal. EOS 69, 16, 341, 1988.

27 A. Eigenhauer, A. Mangini, M. Segl, J. Beer, G. Bonani, M. Suter and W. Wolfli, High-resolution ${ }^{10} \mathrm{Be}$ and ${ }^{230} \mathrm{Th}$ profiles in DSDP 580. Nucl. Instrum. Methodol. Phys. Res. B29, 326-331, 1987.

28 E.L. Hamilton, Elastic properties of marine sediments. J. Geophys. Res. 76, 579-603, 1971.

29 E.L. Hamilton, Sound velocity and related properties of marine sediments, North Pacific. J. Geophys. Res. 75, 4423-4446, 1970.

$30 \mathrm{~K}$. Terzaghi, Undisturbed clay samples and undisturbed clays. J. Boston Soc. Civ. Eng. 28, 211-231, 1941.

31 G.A. Leonards and B.K. Ramiah, Time effects in the consolidation of clay. Am. Soc. Testing Mater. Spec. Tech. Bull. 254, 116-130, 1960.

32 L. Bjerrum and T.H. Wu, Fundamental shear-strength properties of the Lilla Edet clay. Geotechnique 10, 101-109, 1960.

33 L. Bjerrum and K.Y. Lo, Effect of aging of the shearstrength properties of a normally-consolidated clay. Geotechnique 13, 147-157, 1963.

34 R.H. Meade, Factors influencing the pore volume of finegrained sediments under low-to-moderate overburden loads. Sedimentology 2, 235-245, 1963.

35 G.A. Leonards and A.G. Altschaffl, Compressibility of clay. J. Soil Mech. Found. Div., Am. Soc. Civ. Eng. 90, SM5, Part I, 133-155, 1964.

36 S.R. Cohen, Measurement of the viscoelastic properties of water-saturated clay sediments, M.S. Thesis, U.S. Naval Postgraduate School, 1968.

37 B.O. Hardin and W.L. Black, Vibration modulus of normally consolidated clay. J. Soil Mech. Found., Div. Am. Soc. Civ. Eng. 94, SM2, 353-369, 1968.

38 W.K. Humphries and H.E. Wahls, Stress history effects on dynamic modulus of clay. J. Soil Mech. Found., Div. Am. Soc. Civ. Eng. 94, SM2, 371-389, 1968.

39 D.G. Moore, Submarine slumps. J. Sediment. Petrol. 31, 343-357, 1961.

40 D.G. Moore, Shear strength and related properties of sedi- ments from experimental Mohole (Guadalupe site). J. Geophys. Res. 69, 4271-4291, 1964.

41 E.L. Hamilton, Consolidation characteristics and related properties from experimental Mohole (Guadalupe site). J. Geophys. Res. 69, 4257-4269, 1964.

42 A.F. Richards and E.L. Hamilton, Investigations of deepsea sediment cores, 3, Consolidation, in: Marine Geotechnique, A.F. Richards, ed., University of Illinois Press, Urbana, Ill., pp. 93-117, 1967.

43 R.H. Meade, Factors influencing the early stages of the compaction of clays and sands-review. J. Sediment. Petrol. 36, 1085-1101, 1966.

44 R.A., Muller and D.E. Morris, Geomagnetic reversals from impacts on the earth. Geophys. Res. Lett. 13, 1177-1180, 1986.

45 N.J., Shackleton and N. Opdyke, Oxygen isotope and paleomagnetic stratigraphy of Pacific core V28-239 Late Pliocene to Latest Pliocene, in: R.M. Cline and J.D. Hays, eds., Investigations of Late Quaternary Paleoceanography and Paleoclimatology, Geol. Soc. Am. Mem. 145, 449-464, 1976.

46 W.L. Prell, Oxygen and carbon isotope stratigraphies for the Quaternary of Hole 502B: Evidence for two modes of isotopic variability, in: W.L. Prell and J. Gardner et al., eds., Init. Rep. DSDP 68, 455-464, U.S. Gov. Print. Off., Washington, D.C, 1982

47 D.V Kent and D.J. Spariosu, Magnetostratigraphy of Caribbean Site 502 hydraulic piston cores, in: W.L. Prell and J. Gardner et al., eds., Init. Rep. DSDP 68, 419-433, U.S. Gov. Print. Off., Washington, D.C, 1982.

48 N.J. Shackleton and M.A. Hall, Oxygen and carbon isotope stratigraphy of Deep-Sea Drilling Project Hole 552A: PlioPleistocene glacial history, in: D.G. Roberts and D. Schnitker et al., eds., Init. Rep. DSDP 81, 599-609, U.S. Gov. Print. Off., Washington, D.C., 1984.

49 Aksu, A. et al., Oxygen and carbon isotope stratigraphy of ODP Sites 646 and 547: Upper Miocene to Pleistocene history, in: S.P. Srivastava and M. Arthur et al., eds., Proc. ODP, Init. Rep., 105, College Station, Tex.

50 F. Hall, J. Bloemendal, J. King, M. Arthur and A. Aksu, Mid- to Late Quaternary sediment fluxes in the Labrador Sea (ODP Leg 105, Site 646): A synthesis of rock-magnetic, oxygen isotopic, carbonate and planktonic foraminiferal data, in: S.P. Srivastava and M. Arthur et al., eds., Proc. ODP, Init. Rep., 105, College Station, Tex., in press. 